\title{
Nicotinic Receptors in the Brain: Links between Molecular Biology and Behavior
}

\author{
Marina R. Picciotto, Ph.D., Barbara J. Caldarone, Ph.D., Sarah L. King, Ph.D., \\ and Venetia Zachariou, Ph.D.
}

\begin{abstract}
Molecular cloning has elucidated the sequence of a family of acetylcholine receptor subunits that are activated by nicotine. Subsequent studies on the localization of individual subunits and the physiological properties of nicotinic subunit combinations in vitro, have led to identification of subunit compositions of nicotinic receptors that may function in vivo, as the native receptor. A particular challenge for the field has been to use these molecular data to determine which individual nicotinic receptor subtype is responsible for mediating each of the behavioral effects of nicotine. Human and animal studies have shown that nicotine is reinforcing and likely responsible for the addictive properties of tobacco. In
\end{abstract}

addition, nicotine has been shown to have effects on locomotion, cognition, affect, and pain sensitivity. Recent studies combining the techniques of molecular biology, pharmacology, electrophysiology, and behavioral analysis to analyze knock out mice that lack individual subunits of the nicotinic acetylcholine receptor, have helped identify the role of specific nicotinic subunits in some of these complex behaviors. These studies could ultimately be useful in designing specific nicotinic receptor agonists and antagonists that may have uses in the clinic.

[Neuropsychopharmacology 22:451-465, 2000] (C) 2000 American College of Neuropsychopharmacology. Published by Elsevier Science Inc.
KEY WORDS: Nicotine; Knock out mice; Reinforcement; Learning

The physiological effects of nicotine are mediated through binding to, and activation of, nicotinic acetylcholine receptors ( $\mathrm{nAChRs).} \mathrm{These} \mathrm{nAChRs}$ are pentamers made up of subunits that have distinct, but overlapping expression patterns in subsets of neurons. Molecular cloning and in situ hybridization have been used to identify the expression patterns of different nAChR subunits. Parallel pharmacological studies have characterized the various behavioral actions of nicotine in the whole ani-

From the Department of Psychiatry, Yale University School of Medicine, New Haven, CT.

Address correspondence to: Marina R. Picciotto, Department of Psychiatry, Yale University School of Medicine, 34 Park Street, 3rd floor Research, New Haven, CT 06508.

Received September 30, 1999; revised November 10, 1999; accepted November 11, 1999. mal, but it has been difficult to correlate particular subunit compositions of $\mathrm{nAChRs}$ with these nicotine-elicited behaviors. This review will attempt to integrate what is known about the molecular, anatomical, and pharmacological properties of $\mathrm{nAChR}$ subunits with behavioral data, and summarize current opinions about which $\mathrm{nAChR}$ subtypes are responsible for particular behaviors.

\section{MOLECULAR BIOLOGY AND NEUROPHYSIOLOGY OF nAChRs}

Upon binding of ACh or other agonists, $\mathrm{nAChRs}$ allow cations to flow through an intrinsic channel, generally resulting in depolarization of the neuron. To date, 11 different neuronal $\mathrm{nAChR}$ subunits have been identified ( $\alpha 2-\alpha 9$ and $\beta 2-\beta 4$ (discussed in Le Novère and Changeux 1995). High affinity $n A C h R s$ are thought to be made up of $2 \alpha$ and 3 non- $\alpha$ subunits per pentamer 
(Anand et al. 1991; Cooper et al. 1991), whereas a subfamily of nAChRs $(\alpha 7-; \alpha 8)$ form functional homo-pentamers (reviewed in Role 1992; Sargent 1993).

The neuronal nAChR subunits can be divided into subfamilies based on sequence homology and phylogeny (Le Novère and Changeux 1995), as well as pharmacological and physiological properties. $\alpha 1-\alpha 6$ combined with $\beta 2-\beta 4$ would comprise one family and $\alpha 7-\alpha 8$ would comprise the second. $\alpha 9$ has distinct pharmacological properties and is likely to be part of a third family. Functionally, nAChRs can be further divided into those containing the $\beta 2$ subunit combined with various $\alpha$ subunits, which have the highest affinity for nicotine (Picciotto et al. 1995), and those containing the $\beta 4$ subunit combined with various $\alpha$ subunits, which have 10 100 times lower affinity for nicotine (Luetje and Patrick 1991). $\beta 4 / \alpha 3$ subunit-containing $n A C h R s$ are highly expressed in the peripheral nervous system and appear to be essential for fast synaptic transmission in the autonomic ganglia (Xu et al. 1999b). In contrast, the subtypes of $n A C h R$ expressed most highly in the brain are $\beta 2 / \alpha 4$ subunit-containing receptors and $\alpha 7$ subunit-containing, $\alpha$-bungarotoxin binding receptors (Flores et al. 1992: Hill et al. 1993; Wada et al. 1989; Zoli et al. 1995).

In the muscle and autonomic ganglia, nAChRs are concentrated at the neuromuscular junction or the synaptic region (Galzi et al. 1991; Rathouz and Berg 1994). In contrast, at least some subtypes of $\mathrm{nAChR}$ in the brain (those containing the $\beta 2$ subunit) are located diffusely throughout the membrane of the neuron, with no obvious concentration at the synaptic junction (Hill et al. 1993). Furthermore, a large proportion of nicotine binding sites are found on nerve terminals rather than in the post-synaptic membrane (Clarke and Pert 1985).

Several effects of nicotine in the brain may be mediated through neuromodulatory potentiation of the release of neurotransmitters (including acetylcholine, dopamine (DA), glutamate, GABA, norepinephrine, and serotonin) (MacDermott et al. 1999; McGehee and Role 1996; Wonnacott et al. 1989). These effects are probably mediated through presynaptic or preterminal $\mathrm{nAChRs,}$ rather than through traditional neurotransmission in which pre-synaptically released acetylcholine acts on postsynaptic, junctional nAChRs to cause neuronal firing (Léna et al. 1993; Marshall et al. 1997; McGehee et al. 1995; Summers and Giacobini 1995; Vidal and Changeux 1993; Wonnacott et al. 1990; Yang et al. 1996).

Low concentrations of nicotine, consistent with the levels found in the blood of moderate smokers (Henningfield et al. 1983), are sufficient to affect neurotransmitter release and the electrophysiological properties of neurons. For example, nanomolar concentrations of nicotine have been shown to enhance excitatory transmission in cultures of neurons from the medial habenula or the hippocampus (Gray et al. 1996; McGehee et al. 1995). The increase in both ACh and glutamate release appears to be mediated through an $\alpha 7$ subunit-containing $\mathrm{nAChR}$ as it can be blocked by $\alpha$-bungarotoxin and is greatly diminished in the presence of antisense oligonucleotides targeted to the $\alpha 7$ subunit. Nanomolar concentrations of nicotine can also stimulate the firing of dopaminergic neurons (Picciotto et al. 1998; Pidoplichko et al. 1997), as well as the release of DA from striatal synaptosomes (Grady et al. 1992), through an $\alpha 4 / \beta 2$-containing $n A C h R$. The ability of low levels of nicotine to stimulate different neuronal systems raises the possibility that endogenous ACh could stimulate non-synaptic nAChRs through a mechanism resembling volume transmission in which ACh escaping the synapse activates $\mathrm{nAChRs}$ some distance away (volume transmission is reviewed in Zoli et al. 1999a).

\section{GENETIC MANIPULATION OF nAChRs}

Although there is a great deal of information about which subunit combinations are functional in vitro, the $\mathrm{nAChR}$ subunit combinations present and active in vivo are not yet fully identified. Pharmacological antagonists show some selectivity, but most compounds can inhibit many subtypes of nAChR in vivo (Decker et al. 1995). The $\alpha$-conotoxins appear to be fairly specific for different $\mathrm{nAChR}$ subunit pairs in vitro (Cartier et al. 1996). It is not yet known whether the functions affected by these toxins in vivo are carried out by the same subunits identified in vitro, or by subunit pairs that have not yet been tested.

One method of identifying nAChR subunits that are functional in vivo is to use antisense oligonucleotide to transiently decrease the expression of specific subunits. Studies using this technique are compelling, although some problems have been noted for antisense approaches, including problems of specificity, making it useful to complement these studies with other techniques that can be used to manipulate levels of nAChR subunits.

Sympathetic neurons from isolated chick sympathetic ganglia have been treated with antisense oligonucleotides to decrease the expression of $\alpha 3, \alpha 4$, and $\alpha 7$ nAChR subunits selectively (Listerud et al. 1991). In these experiments, treatment with antisense oligonucleotides targeting the $\alpha 3$ subunit abolished one of the primary classes of nicotine-elicited currents, suggesting that this subunit has a primary role in nicotinic transmission in sympathetic ganglia. Antisense oligonucleotides targeting the $\alpha 7$ subunit also shifted the pattern of nicotine-elicited currents, suggesting that this subunit can contribute to the observed currents. The notion that $\alpha 3$ and $\alpha 7$ subunits contribute to ganglionic transmission is further supported by both electrophysiological and immunoprecipitation studies (Sargent 1993).

Additional studies showed that several different cur- 
rents in sympathetic ganglia involve the $\alpha 7$ subunit. This implies that, in addition to forming homomeric nAChRs, the $\alpha 7$ subunits may combine with other $\mathrm{nAChR}$ subunits to form functional receptors in vivo (Yu and Role 1998). Antisense studies have also shown that the $\alpha 5$ subunit can alter the electrophysiological properties of $n A C h R s$ containing the $\alpha 4$ and $\beta 2$ subunits in vivo and is therefore likely to play an important role in nicotinic transmission in those brain areas in which it is expressed (Ramirez-Latorre et al. 1996). Studies of animals treated centrally with antisense oligonucleotides to the $\alpha 6$ subunit have shown a role for this subunit in mediating the locomotor activating effects of nicotine, which implies that it may be involved in modulating the dopaminergic system (Le Novère et al. 1999).

Another useful tool for identifying the role of particular nAChR subunits in behavioral functions of nicotine will be the generation of knock out mice lacking specific nAChR subunits. Knock out mice have been developed lacking the $\beta 2$ subunit (Picciotto et al. 1995), the $\alpha 7$ subunit (Orr-Urtreger et al. 1997), the $\alpha 9$ subunit (Vetter et al. 1997, 1999), the $\alpha 4$ subunit (Marubio et al. 1999), the $\alpha 3$ subunit ( $\mathrm{Xu}$ et al. 1999a), and the $\beta 4$ subunit (Xu et al. 1999b) (Table 1). Knock outs of the $\alpha 5$ subunit (Xu et al. 1997) and the $\beta 3$ subunit (Allen et al. 1998) have been also been reported.

Knock out mice have been used to demonstrate the role of individual $\mathrm{nAChR}$ subunits in effects of nicotine on neurophysiology. Experiments in knock out mice lacking the $\alpha 7$ subunit have shown that a rapidly desensitizing nicotinic current in the hippocampus is mediated through an $\alpha 7$-containing nAChR (Orr-Urtreger et al. 1997). In addition, experiments in $\beta 2$ subunit knock out mice have demonstrated that nAChRs on dopaminergic neurons that mediate nicotine-elicited increases in firing rate contain the $\beta 2$ subunit (Picciotto et al. 1998). The $\beta 2$ subunit is also involved in mediating other presynaptic responses to nicotine, including effects on GABA release (Lu et al. 1998; Marks et al. 1999).

Pharmacological and electrophysiological techniques have also been used on $\beta 2$ subunit knock out mice to characterize $\mathrm{nAChR}$ subtypes in the brain (Zoli et al. 1998). Four types of $n A C h R$ subtypes have been identified (Table 2) extending the characterization of nAChRs based primarily on pharmacology (Alkondon and Albuquerque 1993). Type I nAChRs contain the $\alpha 7$ subunit, account for all $\alpha$-bungarotoxin binding in the brain (Orr-Urtreger et al. 1997), and are unaltered in the $\beta 2$ subunit knock out (Zoli et al. 1998). Type 2 nAChRs contain the $\beta 2$ subunit and bind several nicotinic agonists with high affinity (including epibatidine, nicotine, and cytisine). This class is most potently activated by the nicotinic agonist epibatidine in electrophysiological experiments (nicotine is slightly less potent at activating these receptors and cytisine is not very potent).
Type $2 \mathrm{nAChRs}$ are likely to be composed of $\beta 2 / \alpha 4$ subunits in most brain regions with other $\alpha$ subunits contributing in specific areas. High affinity nicotine binding is completely abolished in $\beta 2$ subunit knock out mice (Picciotto et al. 1995) and nearly absent in $\alpha 4$ subunit knock out mice (Marubio et al. 1999). Despite the overall decrease in high affinity nicotine binding in $\alpha 4$ subunit knock out mice, nicotine binding remains, to some extent, in the interpeduncular nucleus and epibatidine binding remains in the substantia nigra and superior colliculus. This suggests that other $\alpha$ subunits can combine with the $\beta 2$ subunit in these brain areas to form functional Type 2 nAChRs (Marubio et al. 1999). Binding experiments using $\alpha$-conotoxin MII suggest that the $\beta 3$ subunit combines with $\beta 2$ subunit-containing nAChRs in some brain areas, including the dopaminergic system, since $\beta 3$ subunit knock out animals show decreased binding of $\alpha$-conotoxin MII, whereas knock out of the $\beta 2$ subunit completely-abolishes $\alpha$-conotoxin MII binding (Allen et al. 1998; Whiteaker et al. 1998).

Type $3 \mathrm{nAChRs}$ are probably composed of $\beta 4 / \alpha 3$ subunits, bind epibatidine (but not nicotine or cytisine) with high affinity in equilibrium binding experiments, and respond most potently to epibatidine in electrophysiological experiments (nicotine and cytisine are equally effective agonists).

Type 4 nAChRs selectively bind cytisine and epibatidine with high affinity in equilibrium binding experiments. These nAChRs contain the $\beta 4$ subunit and respond most potently to epibatidine, but type $4 \mathrm{nAChRs}$ exhibit faster desensitization than type $3 \mathrm{nAChRs}$ at high doses of nicotine. Future experiments using mice lacking other $\mathrm{nAChR}$ subunits should allow a finer definition of these receptor classes.

\section{BEHAVIORAL EFFECTS OF NICOTINE AND RELATION TO nAChR SUBTYPES}

Nicotine affects many aspects of behavior including locomotion, nociception, anxiety, learning and memory, as well as behaviors associated with drug abuse (Decker et al. 1995). Several studies have also shown positive and negative associations of smoking with psychiatric and neurological illnesses. The rate of smoking is much higher in schizophrenics (up to $90 \%$ ) (Nisell et al. 1995), depressed patients (up to 65\%) (Breslau 1995), and alcoholics (up to 90\%) (Burling and Ziff 1988) than in the general population. In contrast, smoking is negatively correlated in some studies with the incidence of Parkinson's disease and Alzheimer's disease (James and Nordberg 1995). Given the wide diversity of behavioral effects mediated by nicotine in human smokers and animal models, it seems possible that these effects are mediated through selective activation of different nAChR Subtypes (see Table 3). 
Table 1. Knock Outs of nAChR Subunits

\begin{tabular}{|c|c|c|c|c|}
\hline Subunit & Localization & KO & KO Phenotype & Refs \\
\hline$\alpha 2$ & $\begin{array}{l}\text { Primarily IPN } \\
\text { Some cortical layers/ } \\
\text { olfactory nucleus }\end{array}$ & Not reported & - & Wada et al. 1989 \\
\hline$\alpha 3$ & $\begin{array}{l}\text { Autonomic ganglia } \\
\text { Primarily MhB, } \\
\text { dorsocaudal medulla } \\
\text { Some cortex, VTA }\end{array}$ & $\begin{array}{l}\text { High mortality } \\
\text { before and } \\
\text { after weaning }\end{array}$ & $\begin{array}{l}\text { Impaired growth, megacystis (inflamed } \\
\text { urinary bladder) and mydriasis } \\
\text { (widely dilated ocular pupils) }\end{array}$ & $\begin{array}{r}\text { Wada et al. 1989; } \\
\text { Xu et al. 1999a }\end{array}$ \\
\hline$\alpha 4$ & Throughout brain & Viable & Reduced antinociception & Marubio et al. 1999 \\
\hline$\alpha 5$ & $\begin{array}{l}\text { Autonomic ganglia } \\
\text { Primarily MhB, } \\
\text { dorsocaudal medulla, } \\
\text { hippocampus, SN } \\
\text { Some cortex }\end{array}$ & Viable & Not yet reported & Xu et al. 1997 \\
\hline$\alpha 6$ & $\begin{array}{l}\text { Primarily LC, VTA, SN } \\
\text { Some supramammilary, } \\
\text { reticular thalamus, } \\
\text { mesencephalic V }\end{array}$ & Not reported & - & Le Novère et al. 1996 \\
\hline$\alpha 7$ & $\begin{array}{l}\text { Throughout brain } \\
\text { High in cortex, } \\
\text { hippocampus, amygdala } \\
\text { Low in thalamus }\end{array}$ & Viable & $\begin{array}{l}\text { Largely normal } \\
\text { Lack MLA-sensitive nicotine response } \\
\text { in hippocampal interneurons } \\
\text { May have slightly decreased anxiety } \\
\text { response }\end{array}$ & $\begin{array}{l}\text { Orr-Urtreger et al. 1997; } \\
\text { Paylor et al. 1998; } \\
\text { Seguela et al. } 1993\end{array}$ \\
\hline$\alpha 9$ & $\begin{array}{l}\text { Cochlear hair cells, skeletal } \\
\text { muscle of the tongue, } \\
\text { hypophysis, nasal } \\
\text { epithelium }\end{array}$ & Viable & $\begin{array}{l}\text { Involved in cochlear efferent } \\
\text { innervation development and function }\end{array}$ & $\begin{array}{l}\text { Elgoyhen et al. 1994; } \\
\text { Vetter et al. } 1999\end{array}$ \\
\hline$\beta 2$ & $\begin{array}{l}\text { Autonomic ganglia } \\
\text { throughout brain, very } \\
\text { high in thalamus }\end{array}$ & Viable & $\begin{array}{l}\text { Lack nicotine-induced increases in } \\
\text { passive avoidance, reinforcement, } \\
\text { antinociception } \\
\text { Show increased neurodegeneration } \\
\text { during aging }\end{array}$ & $\begin{array}{l}\text { Marubio et al. 1999; } \\
\text { Picciotto et al. 1995, } \\
\text { 1998; Zoli et al. 1998, } \\
\text { 1999b }\end{array}$ \\
\hline$\beta 3$ & $\begin{array}{l}\text { LC, VTA, SN } \\
\text { Wider brain expression but } \\
\text { mostly co-localization } \\
\text { with } \alpha 6\end{array}$ & Viable & Altered locomotor activity & $\begin{array}{l}\text { Allen et al. 1998; Le } \\
\text { Novère et al. } 1996\end{array}$ \\
\hline$\beta 4$ & $\begin{array}{l}\text { Autonomic ganglia } \\
\text { Primarily IPN, MhB, } \\
\quad \text { dorsocaudal medulla } \\
\text { Some superior colliculus, } \\
\text { medial geniculate }\end{array}$ & Viable & $\begin{array}{l}\text { Viable, but lethal when combined with } \\
\text { } 32 \text { subunit knock out }\end{array}$ & $\begin{array}{l}\text { Dineley-Miller and } \\
\text { Patrick 1992; Wada et } \\
\text { al. 1989; Xu et al. 1997, } \\
\text { 1999b }\end{array}$ \\
\hline
\end{tabular}

Abbreviations: IPN, interpeduncular nucleus; MhB, medial habenula; LC, locus coeruleus; VTA, ventral tegmental area; SN, substantia nigra; MLA, $\alpha 7$ antagonist methyllyaconitine.

Knock out mice have been used to examine the role of nAChR subtypes in a few of the behavioral actions of nicotine. At present, most of the information available on nAChR subtypes involved in behavior comes from pharmacological or anatomical studies. In this portion of the review, we will describe some of the behavioral actions of nicotine and attempt to correlate these data both with the anatomical locus of action of nicotine and the potential $\mathrm{nAChR}$ subtypes that might mediate the behavioral effect.

Only the $\alpha 3$ subunit appears to be necessary for survival (Xu et al. 1999a). Mice lacking the $\alpha 4, \alpha 5, \alpha 7, \beta 2$, $\beta 3$, or $\beta 4$ subunits are all viable and appear grossly nor- mal (Allen et al. 1998; Marubio et al. 1999; Orr-Urtreger et al. 1997; Picciotto et al. 1995; Xu et al. 1997, 1999b). One drawback of studies with knock out mice that should he mentioned is that these animals lack the subunit of interest throughout development, and thus adaptations in neural circuitry may affect the interpretation of behavioral changes in these animals. Future studies of animals with conditional or inducible knock out of individual subunits will further refine the conclusions that can be drawn about the role of nAChRs in adult behavior. There are still many gaps in our knowledge of the subtypes of $\mathrm{nAChR}$ mediating specific behavioral actions of nicotine. However, genetic engineer- 
Table 2. Classification of nAChR-Mediated Currents

\begin{tabular}{|c|c|c|c|c|}
\hline Class & $\begin{array}{c}\text { Electrophysiological } \\
\text { Response }\end{array}$ & Ligand Binding Profile & Subunit Composition & Localization \\
\hline Type 1 & $\begin{array}{l}\alpha B T X \text { and MLA-sensitive, } \\
\text { very fast desensitization }\end{array}$ & $\alpha \mathrm{BTX}$ & $\alpha 7$ & Throughout brain \\
\hline Type 2 & $\begin{array}{l}\text { MLA-insensitive, NIC }>> \\
\text { CYT, DH } \beta E=\mathrm{MCA}\end{array}$ & $\begin{array}{l}\mathrm{EPI}>\mathrm{NIC}=\mathrm{CYT}=\mathrm{MCC}=\mathrm{ACH} \\
\quad \text { (high affinity for nicotine) }\end{array}$ & $\begin{array}{l}\beta 2 / \alpha 4 \\
\beta 2 / \alpha 2 \text { ? (non } \alpha 4) \\
\beta 2(\text { non } \alpha 4) \\
\beta 2 / \alpha 6 / \beta 3 \\
\beta 2 / \text { ? }\end{array}$ & $\begin{array}{l}\text { Throughout brain } \\
\text { IPN } \\
\text { SN + SC } \\
\text { LC (type A) } \\
\text { Hippocampus }\end{array}$ \\
\hline Type 3 & $\begin{array}{l}\text { MLA-insensitive, CYT = } \\
\text { NIC, DH } \beta E<\text { MCA, slow } \\
\text { decay at } 100 \mu \mathrm{m} \mathrm{NIC}\end{array}$ & $\begin{array}{l}\text { EPI } \\
\text { (low affinity for nicotine) }\end{array}$ & $\begin{array}{l}\beta 4 / \alpha 3 / \alpha 5 ? \\
\beta 4 / \alpha 3\end{array}$ & $\begin{array}{l}\text { MhB, IPN, dorsal medulla } \\
\text { LC (type B), autonomic ganglia }\end{array}$ \\
\hline Type 4 & $\begin{array}{l}\text { MLA-insensitive, CYT }= \\
\text { NIC, DH }<\text { E MCA, fast } \\
\text { decay at } 100 \mu \mathrm{m} \text { NIC }\end{array}$ & $\mathrm{EPI}>\mathrm{CYT}>\mathrm{MCC}=\mathrm{ACH}$ & $\begin{array}{l}\beta 4 / \alpha 4 ? \\
\beta 4 / \alpha 2 ?\end{array}$ & $\begin{array}{l}\text { Lateral MhB } \\
\text { Dorsal IPN }\end{array}$ \\
\hline
\end{tabular}

Based on Zoli et al. 1998 with some additional information from Léna et al. 1999; Marubio et al. 1999; and Xu et al. 1999a, 1999b.

Abbreviations: NIC, nicotine; CYT, nicotinic agonist cytisine; EPI, nicotinic agonist epibatidine; MCC, nicotinic agonist methyl carbamylcholine; $\mathrm{ACH}$, acetylcholine; MCA, nicotinic antagonist mecamylamine; DH $\beta E$, nicotinic antagonist dihydro- $\beta$-erythroidine; MLA, $\alpha 7$ antagonist methyllyaconitine; $\alpha \mathrm{BTX}, \alpha 7$ antagonist $\alpha$-bungarotoxin; IPN, interpeduncular nucleus; SN, substantia nigra; SC, superior colliculus; MhB, medial habenula; LC, locus coeruleus.

ing has advanced the fields of behavioral pharmacology and molecular biology to allow such questions to be addressed in behaving animals.

\section{Nicotine Reinforcement and Withdrawal}

Behavioral Studies. Nicotine is thought to be the primary substance in cigarette smoke responsible for addiction to tobacco (US Department of Health and Human Services 1988) and several behavioral paradigms have been used to demonstrate the reinforcing properties of nicotine in animal models. Nicotine can condition a place preference in rodents (Shoaib et al. 1994), although the parameters under which place preference can be conditioned are limited (Clarke and Fibiger 1987) and are likely to be affected by many environmental and genetic factors. Nicotine self-administration has also been demonstrated in several species and, again, the parameters under which animals self-administer nicotine are more limited than for cocaine selfadministration. This may resemble the intermittent pattern of nicotine administration from smoking (Corrigall and Franklin 1989; Cox et al. 1984; Risner and Goldberg 1983).

Nicotine has complex effects on locomotion. In a familiar environment nicotine administration can result

Table 3. Potential Anatomical and Molecular Substrates for the Behavioral Actions of Nicotine

\begin{tabular}{llc}
\hline Behavior & \multicolumn{1}{c}{ Possible Sites of Nicotine Action } & Potential nAChR Subtypes \\
\hline $\begin{array}{l}\text { Reinforcement } \\
\text { Sensitization }\end{array}$ & Mesolimbic DA system (VTA-NAc) & $\alpha 4 / \beta 2 / \alpha 6 / \beta 3$ \\
Locomotion & VTA & $\alpha 7 ; \alpha 4 / \beta 2 / \alpha 6 / \beta 3$ \\
$\quad$-hyper & VTA and NAc & $\alpha 4 / \beta 2 / \alpha 6 / \beta 3$ \\
$\quad$ hypo & MHb and IPN & $\alpha 3 / \beta 4 ; \alpha 2 / \beta 4$ \\
Antinociception & Raphe and thalamus & $\underline{\alpha} / \beta 2$ \\
& Spinal & non $\alpha 4(\alpha 3 / \beta 4)$ \\
Working memory & Hippocampus, cortex & $?$ \\
Fear associated learning & Amygdala, brainstem, thalamo-cortical pathway & $\alpha 4 / \beta 2$ \\
Neurodegeneration & Hippocampus & $\alpha 4 ? / \beta 2$ \\
& Cortex & $\alpha 4 / \beta 2$ \\
Anxiety & Septo-hippocampal system & $\alpha 7$ \\
Depression & Septo-hippocampal system & $\alpha 4 / \beta 2, \alpha 7 ?$ \\
& Hypothalamus, pituitary, adrenal axis & $\alpha 4 / \beta 2, \alpha 7 ?$ \\
Latent inhibition pre-pulse inhibition & NAc, PPN & $\alpha 4 / \beta 2$ \\
& Hippocampus & $\alpha 7$ \\
\end{tabular}

Possible nAChR subunit compositions suggested from experiments with knock out mice (underlined).

Abbreviations: VTA, ventral tegmental area; NAc, nucleus accumbens; MHb, medial habenula; IPN, interpeduncular nucleus; PPN, pedunculopontine tegmental area; DA, dopamine. 
in locomotor activation (Clarke et al. 1988). Repeated nicotine injection also results in sensitization to further nicotine challenge (Clarke and Kumar 1983; Museo and Wise 1990), an effect that has been associated with administration of psychostimulants. In contrast, acute treatment of a naive rodent with nicotine in a novel environment results in rapid locomotor depression (Marks et al. 1989), an effect that exhibits tolerance upon subsequent nicotine injection (Marks et al. 1991).

In humans, nicotine withdrawal following smoking cessation is characterized by weight gain, irritability, anxiety, insomnia, depression, and difficulty concentrating (Hughes et al. 1994). In rats, nicotine withdrawal is similar to opioid withdrawal and involves shakes, ptosis, genital licks, teeth chatter, and changes in locomotor activity (Hildebrand et al. 1997; Malin et al. 1992). Spontaneous nicotine withdrawal in rats also results in a decrease in brain reward thresholds similar to the decrease seen with other drugs of abuse (EppingJordan et al. 1998). Precipitation of nicotine withdrawal by administration of a nicotinic antagonist following chronic nicotine treatment can condition a place aversion, indicating that nicotine withdrawal results in negative affect (Suzuki et al. 1996).

Several studies have also shown an interaction between nicotine and other drugs of abuse. Pre-exposure to drugs of abuse such as morphine and amphetamine can potentiate nicotine reinforcement. For example, in the brain stimulation reward model, both drugs decrease the dose of nicotine required to lower the self-stimulation threshold (Huston-Lyons et al. 1993). Conversely, prior exposure to nicotine enhances the conditioned rewarding effects of morphine (Shippenberg et al. 1996), accelerates the acquisition of ethanol drinking behavior in naive rats (Smith et al. 1999) and predisposes rats to self-administer a low dose of cocaine (Horger et al. 1992). In the place preference paradigm, nicotine can potentiate the action of low doses of cocaine, whereas antagonism of $\mathrm{nAChRs}$ decreases the response to a threshold dose of cocaine (Zachariou et al. 1997).

\section{Neuroanatomical and Lesion Studies}

The reinforcing effects of nicotine are thought to be mediated via the mesolimbic DA system (the ventral tegmental area (VTA) and its projections to the nucleus accumbens (NAc)) which is known to mediate the action of many drugs of abuse (Koob 1992). Nicotine selfadministration is decreased following lesion of the mesolimbic DA system (Corrigall et al. 1992). Furthermore, injection of nicotine directly into the VTA can condition a place preference (Museo and Wise 1994). The locomotor activating effects of nicotine are also mediated through stimulation of the dopaminergic system since injection of nicotine directly into the VTA or NAc re- sults in increased locomotion (Museo and Wise 1990, 1995) and locomotor sensitization is decreased following lesion of the VTA (Corrigall et al. 1992). In contrast, nicotine-induced hypoactivity is mediated through the interpeduncular nucleus, a brain area with the highest expression of the $\beta 4$ subunit, showing that the ability of nicotine to depress locomotion is anatomically distinct from its locomotor activating effects (Hentall and Gollapudi 1995).

In vivo microdialysis has been used to demonstrate that nicotine can augment DA release in the striatum and NAc of rodents (Benwell and Balfour 1992; Marshall et al. 1997). The effect of nicotine on DA levels may be due in part to activation of nAChRs on DA terminals, as nicotine-elicited DA release can be seen in purified synaptosome preparations from the NAc that are highly enriched in presynaptic elements (Grady et al. 1992; Rowell 1995; Wonnacott et al. 1990). Although injection of a nicotinic agonist directly into the DA terminal fields of the NAc can stimulate DA release, the strongest effects of nicotine appear to be on the DA cell bodies of the VTA (Mifsud et al. 1989). In addition, nicotine infusion into the VTA produces a longer-lasting effect on DA release than infusion into the NAc (Nisell et al. 1994). Nicotine self-administration also results in increased expression of the chronic Fos-related antigens in the NAc (Merlo Pich et al. 1997), which are transcription factors that may be involved in neuroadaptation following chronic treatment with drugs of abuse (Kelz et al. 1999; Nye and Nestler 1996).

Changes in mesolimbic DA function are also seen following nicotine withdrawal. Nicotine withdrawal results in changes in the firing pattern of VTA neurons (Rasmussen and Czachura 1995) and mecamylamineprecipitated withdrawal results in reduced DA output in the NAc, as has been seen following withdrawal from other drugs of abuse (Hildebrand et al. 1998).

\section{Genetic Models}

Nicotine reinforcement has been studied in knock out mice lacking the $\beta 2$ subunit of the nAChR (Picciotto et al. 1998). In the absence of the $\beta 2$ subunit, neurons in the DA system are grossly normal, but nicotine fails to induce DA release in the Nac, and DA neurons in the VTA become unresponsive to nicotine. Nicotine selfadministration is also abolished in these mice, suggesting that the $\beta 2$ subunit is a component of the nAChR mediating nicotine reinforcement. Studies using glutamatergic antagonists and the $\alpha 7$-selective antagonist methyllycaconitine in rat have suggested that $\alpha 7$ subunit-containing receptors localized presynaptically on glutamatergic afferents in the VTA contribute to the stimulation of DA release in the NAc (Schilstrom et al. 1998a,b). Although these receptors may contribute to the stimulation of DA release in the NAc in mice (Schil- 
strom et al. 1998a,b), they are less likely to be the primary mediators of nicotine reinforcement since mice lacking the $\beta 2$ subunit showed normal levels of $\alpha$-bungarotoxin binding. One possibility is that the $\alpha 7$-mediated effect on glutamatergic terminal in the VTA is responsible for the plasticity induced by repeated nicotine treatment, and that this effect leads to sensitization of both DA release and locomotor activity following repeated nicotine treatment. Experiments using $\alpha 7$ knock out mice will be very useful for exploring this hypothesis.

\section{Antinociception}

Behavioral Studies. Both nicotine (Tripathi et al. 1982) and the nicotinic agonist epibatidine (Traynor 1998) are antinociceptive. Nicotinic compounds increase the latency for rodents to perform the tail flick response, escape from a hot plate or perform the paw lick response. Recently, a ligand which is thought to activate $\alpha 4 / \beta 2$-containing nAChRs (ABT-594) has been developed that shows antinociceptive properties which are blocked by the nicotinic antagonist mecamylamine and which are equal in efficacy to those of morphine when tested in animal models of acute thermal, persistent chemical, and neuropathic pain (Donnelly-Roberts et al. 1998). One of the major advantages of ABT-594 is that chronic administration does not elicit opioid-like withdrawal or physical dependence (Bannon et al. 1998). These studies suggest that $\mathrm{nAChRs}$ containing the $\alpha 4$ and $\beta 2$ subunits are found on neurons in pathways modulating pain response.

Neuroanatomical and Lesion Studies. Nicotine-induced antinociception is mediated through both the cholinergic and opioidergic systems (Zarrindast et al. 1997) and is enhanced by agents that increase intracellular calcium through L-type channels (Damaj and Martin 1993). Nicotine can also potentiate morphine but not $\delta$ and $\kappa$ opioid receptor-mediated antinociception (Suh et al. 1996) and upregulates $\mu$ opioid receptors in striatum (Wewers et al. 1999). Brain areas mediating nicotineinduced antinociception are thought to include the thalamus, raphe magnus, and the pedunculopontine tegmental nucleus (Bitner et al. 1998; Jurna et al. 1993). nAChRs are also present in capsaicin-sensitive neurons, including primary afferents and dorsal root ganglia (Roberts et al. 1995). These nociceptive pathways express many subtypes of nAChR (Zoli et al. 1995). The widespread localization of nAChRs could support a role for nicotine-induced antinociception at many levels.

Genetic Models. Knock out mice lacking either the $\alpha 4$ or the $\beta 2$ subunit have been used to identify particular nAChR subunits mediating the antinociceptive effects of nicotine (Marubio et al. 1999). The lack of either the $\alpha 4$ or $\beta 2$ subunit results in reduced nicotine-elicited antinociception in the hot plate test and diminished sensi- tivity to nicotine in the tail flick test. Patch clamp recordings in areas implicated in supraspinal nicotine antinociception, such as serotonergic neurons in the raphe magnus and neurons in the thalamus, showed a loss of nicotine-elicited currents in $\alpha 4-/-$ or $\beta 2-/-$ mice. In contrast, recordings from superficial laminae of the dorsal horn showed a nicotine-induced augmentation of postsynaptic currents, indicating that nicotine's spinal antinociception is mediated via non $\alpha$ receptors, most likely $\alpha 3$ and $\beta 4$ containing $n A C h R s$.

\section{Nicotine, Learning and Memory, and Neurodegenerative Disorders}

Behavioral Studies. Nicotine has been reported to improve performance in tests measuring several forms of learning and memory. Working memory, spatial learning, and fear-associated learning have been measured in rodents in the radial arm maze, the Morris water maze and the passive avoidance task, respectively (reviewed in Levin 1992). The effects of nicotine appear to be most robust for working memory (reviewed in Levin 1992; Levin and Simon 1998). In contrast, nicotine appears to have little effect on longer term forms of memory such as reference memory. When a degree of proactive interference is built into a working memory task, nicotine can impair learning (Dunnett and Martel 1990). Nicotine has also been reported to enhance contextual fear conditioning (Gould and Wehner 1999), as well as retention of an inhibitory avoidance response in the passive avoidance task, particularly when administered immediately post-training (Faiman et al. 1991).

Many of the observed improvements in learning mediated by nicotine, particularly those in spatial learning tasks such as the Morris maze, are not seen in unimpaired animals, but instead are only observed following aging or brain lesion (Levin 1992). Treatment of Alzheimer's patients with nicotine has been shown to attenuate the decline in some of the cognitive deficits symptomatic of the disease and is particularly effective in reversing attentional deficits (Lawrence and Sahakian 1998). One of the recognized pathologies in the brains of Alzheimer's patients is a loss of neurons in the basal forebrain complex that provide cholinergic input into neocortex. Receptor binding studies on postmortem Alzheimer's brains have also shown a reduction in high affinity nicotine binding, suggesting that $\beta 2$ subunit-containing nAChRs are lost in these patients (Nordberg 1994).

Neuroanatomical and Lesion Studies. Lesions of cholinergic nuclei have been used extensively to examine modulation of learning and memory (Everitt and Robbins 1997). Nicotine has been shown to restore performance in several learning paradigms following lesions of cholinergic nuclei (Levin 1992). For example, nicotine 
is able to restore passive avoidance performance in animals with nucleus basalis but not basolateral amygdala (BLA) lesions (Riekkinen et al. 1993), suggesting that $\mathrm{nAChRs}$ in the BLA may be a potential site for nicotinic modulation of passive avoidance. Lesioning and infusion studies show that norepinephrine release in the BLA is essential in passive avoidance learning (McGaugh et al. 1996). Nicotine may exert its effects directly by stimulating brainstem norepinephrine cells that project to the BLA (Fu et al. 1998). Alternatively, modulation of norepinephrine release in the BLA by GABA, opiate, and cholinergic agonists can alter passive avoidance learning (see McGaugh and Cahill 1997 for review). Nicotine may, thus, modulate norepinephrine release indirectly by stimulating the release of any of these other neurotransmitters. Modulatory effects of nicotine could also occur in projections from the thalamus and the cortex where sensory information is likely to be processed before converging on the BLA where memory of the event is consolidated (McGaugh and Cahill 1997).

Genetic Models. Two lines of nAChR subunit knock out mice have been tested in learning and memory tasks to date. $\beta 2$ subunit knock out mice, which lack high affinity receptors throughout the brain, show a slight increase in baseline passive avoidance performance that cannot be enhanced by nicotine, implicating a $\beta 2$ subunit-containing $n A C h R$ in mediating the effects of nicotine on this behavior (Picciotto et al. 1995). These animals also show normal spatial learning as adults, but demonstrate an impairment in spatial learning following aging, suggesting that $\beta 2$ subunit-containing nAChRs are necessary for maintenance of cognitive function in aged animals (Zoli et al. 1999b).

Aged $\beta 2$ knock out mice also show increased cortical and hippocampal atrophy. Thus, it is not yet known whether this spatial learning deficit is attributable to a $\beta 2$ receptor involvement in the task, increased neurodegeneration, or both. Nicotine has been shown to protect primary cells in culture from cell death induced by excitotoxic amino acids (Borlongan et al. 1995; Marin et al. 1994) and it has been suggested that there is an inverse correlation between smoking and the incidence of Alzheimer's disease (van Duijn and Hofman 1991). These data, taken together, may suggest a neuroprotective function for nAChRs with high affinity for nicotine. Aged $\beta 2$ knock outs also have an increased level of circulating corticosterone (Zoli et al. 1999b) which could be either a cause or a consequence of the hippocampal degeneration seen. Chronic elevation of circulating glucocorticoids can lead to selective degeneration of CA3 hippocampal neurons (McEwen and Sapolsky 1995), whereas atrophy of CA3 neurons has been shown to lead to elevated corticosterone levels (Brown et al. 1999). $\alpha 7$ subunit knock out mice show no baseline differ- ences in fear conditioning, spatial learning and passive avoidance compared to their wild type litter mates (Paylor et al. 1998). A subtle difference was seen in latency to find the hidden platform in the Morris Water maze test, but no differences were seen in probe trials and the authors stat that the decreased escape latency may reflect a feature of these knock outs other than learning. To date the effects of nicotine or aging on these learning paradigms in $\alpha 7$ knock out mice has not been reported and it will be interesting to see whether these mice show differential sensitivity to nicotine in learning tasks.

\section{Smoking, Anxiety, and Affective Disorders}

Behavioral Studies. High rates of smoking have been seen among patients with affective disorders. This suggests that nicotine may be acting to relieve symptoms of anxiety and depression (Breslau 1995). Nicotine has been reported to produce antidepressant effects even in non-smokers (Salin-Pascual et al. 1995, 1996); however, little is known about the specific $\mathrm{nAChR}$ subtypes involved in the actions of nicotine in affective disorders.

Studies using behavioral models of anxiety and depression in rodents also suggest that nicotine can have both anxiolytic-like and antidepressant-like effects in animals. An anxiolytic-like effect of nicotine has been demonstrated in several tests of anxiety. These include the elevated plus maze (Brioni et al. 1993), the mirrored chamber (Cao et al. 1993), the light-dark chamber (Costall et al. 1989), fear-potentiated startle (Vale and Green 1996), and the social interaction test (File et al. 1998). Nicotine has also been shown to have antidepressantlike effects in rats in the learned helplessness (Semba et al. 1998) and forced swim (Tizabi et al 1999) models of depression.

Neuroanatomical and Lesion Studies. The cholinergic septo-hippocampal system has been implicated in the control of anxiety and depression (Gray 1988). In the elevated plus maze, septal lesions (Menard and Treit 1996; Treit and Menard 1997) have been shown to have anxiolytic effects. Nicotine has also been shown to act directly on the hippocampus to produce anxiolytic effects. Administration of nicotine directly into the dorsal hippocampus produces anxiolytic-like effects in both the plus maze (Ouagazzal et al. 1999) and social interaction tests (File et al. 1998). The behavioral deficits associated with learned helplessness have been prevented by lesions to the hippocampus (Elmes et al. 1975) and the ventromedial septum (Kelsey and Baker 1983). Projections from the hippocampus to the amygdala may, therefore, be involved in forming emotional memories associated with learned helplessness-inducing shock. Nicotine may thus produce its antidepressantlike effects by acting directly on the hippocampus and/ or septum, or through the projection to amygdala. 
Depressed patients exhibit elevated serum concentrations of cortisol and abnormal depression of cortisol levels in response to dexamethasone treatment (Kathol et al. 1989; Rush et al. 1996). In mice, chronic exposure to corticosterone decreases $\alpha$-bungarotoxin binding in several brain regions including the hippocampus, and hypothalamus (Pauly and Collins 1993).

Genetic Models. Knock out mice lacking the $\beta 2$ subunit of $\mathrm{nAChR}$ showed no differences from wild type controls in the light-dark box, mirrored chamber, and elevated plus maze tests for anxiety-related behavior (Picciotto et al. 1997). Knock out mice lacking the $\alpha 7$ subunit of the $\mathrm{nAChR}$ were not different from wild type controls in the light-dark test; however, in an open field test $\alpha 7$ knock outs spent a greater proportion of total distance traveled in the center of the arena in comparison to wild type mice, suggesting $\alpha 7$ knock outs may show less anxiety-related behavior (Paylor et al. 1998). Furthermore, as mentioned above, $\alpha 7$ knock out mice located a hidden platform more quickly than wild-type mice in the Morris water maze (Paylor et al. 1998). The $\alpha 7$ knock out mice may show faster acquisition of the water task because they exhibit less anxiety upon exposure to water. Because basal levels of anxiety related behavior are normal in $\beta 2$ knock out mice, or show only subtle differences in $\alpha 7$ knock outs, these mice can be used to examine the effects of nicotine on tests of anxiety without baseline differences which could make interpretations of behavioral data difficult.

In the forced swim model of depression, the antidepressant effect of nicotine was observed in the Flinders Sensitive Line (FSL) of rats, but was not seen in the Flinders Resistant Line (FRL) (Tizabi et al. 1999). FSL rats, which were selectively bred for increased sensitivity to anticholinesterase agents, have been proposed as an animal model of depression (Overstreet 1993), because they have lower body weight, lower locomotor activity, increased REM learning difficulties, anhedonia when exposed to chronic mild stress, and greater immobility in the forced swim test. FSL rats have higher cytisine binding in midbrain, cortex, and striatum compared to FRL rats, although no differences in $\alpha$-bungarotoxin binding were observed between the two lines (Tizabi et al. 1999). These results are consistent with a possible role for $\alpha 4 / \beta 2$-containing $n A C h R$ subtypes in pathways underlying depression and in mediating The antidepressant-like properties of nicotine.

\section{Smoking and Schizophrenia}

Behavioral Studies. Epidemiological studies report high rates of smoking among schizophrenic patients, with estimates as high as $90 \%$ as compared to $20-30 \%$ in the general population (Nisell et al. 1995). One possible explanation might be that patients are smoking to help alleviate the attentional deficits associated with schizophrenia. One model of sensory filtering or gating used to investigate the attentional deficit in schizophrenia is pre-pulse inhibition (PPI), in which the presentation of one stimulus inhibits the response to a second stimulus. Schizophrenics show abnormal sensory filtering (Adler et al. 1982: Baruch et al. 1988), and nicotine has been reported to alleviate some of these deficits (Adler et al. 1993, 1998). Animal studies also suggest that nicotine may act to facilitate sensory inhibition. Nicotine can enhance PPI in mice (Stevens and Wear 1997) and rats (Acri et al. 1991, 1994).

Another model of the attention deficit associated with schizophrenia is latent inhibition (LI), in which pre-exposure to a stimulus inhibits subsequent conditioning to that stimulus (Feldon and Weiner 1992; Gray 1998). Although one study failed to find differences in LI between smokers and nonsmokers (Thornton et al. 1996), other studies have reported that smokers have enhanced LI, which is dependent upon the pre-exposure parameters (Della Casa et al. 1999a,b). Similar findings have been reported in rats, with nicotine either enhancing or disrupting LI, depending on the pre-exposure parameters (Joseph et al. 1993; Rochford et al. 1996).

Neuroanatomical and Lesion Studies. Electrolytic lesions of the NAc disrupt PPI (for review see Swerdlow et al. 1992). Nicotine increases DA release in the NAc, suggesting that it may mediate PPI through its effects on DA systems. However, it is unlikely that nicotine acts directly to enhance PPI through this system, because increased DA levels have been shown to disrupt PPI (Weiner and Feldon 1997). Lesions of the pedunculopontine nucleus have also been shown to block PPI (Swerdlow et al. 1992), and nicotine may act directly on this nucleus to enhance PPI. Lesions of the hippocampus, septum, medial raphe (for review see Weiner 1990), and NAc (for review see Weiner and Feldon 1997) disrupt LI. Since agents that promote DA release, such as amphetamine, block LI, it is thought that nicotine may act to disrupt LI by promoting DA release in NAc (Weiner and Feldon 1997). Nicotine may also act to enhance LI through direct effects on nAChRs in the septo-hippocampal system.

One brain area that may mediate the effect of nicotine on sensory gating in schizophrenia is the hippocampus. Postmortem studies have shown a reduced number of $\alpha$-bungarotoxin-sensitive nAChRs in the hippocampus in schizophrenic patients (Freedman et al. 1995). In rats, infusions of the cholinergic agonist carbachol into the hippocampus disrupt PPI (Caine et al. 1991). In mice, PPI has been correlated with the number of $\alpha$-bungarotoxin binding sites in the hippocampus. Inbred mouse strains (such as the DBA/2J strain) that showed the poorest PPI, also had the smallest numbers of $\alpha$-bungarotoxin binding sites (Stevens et al. 1996). Pharmacological studies also provide evidence for a role of the $\alpha 7 \mathrm{nAChR}$ in PPI in rodents. The nicotinic 
agonists GST21, DMXBm, and DMAC, which act on the $\alpha 7$ receptor, normalized PPI in DBA mice (Stevens et al. 1998). In rats, PPI was attenuated by central administration of $\alpha$-bungarotoxin (Luntz-Leybman et al. 1992) and central injections of antisense oligonucleotides to the $\alpha 7$ subunit (Rollins et al. 1993). However, the non- $\alpha 7$-selective nicotinic agonists cytisine and lobeline can augment LI under the same conditions that nicotine increases LI, suggesting that activation of $\mathrm{nAChRs}$ that do not contain the $\alpha 7$ receptor can augment attention in the LI model (Rochford et al. 1996).

Genetic Models. The PPI deficit in schizophrenic patients has been linked to chromosome 15q13-14, in the region of the $\alpha 7$ subunit gene (Freedman et al. 1997). Adult $\alpha 7$ knock out mice show normal PPI, however (Paylor et al. 1998). These data suggest that the $\alpha 7$ subunit of the nAChR is not reponsible for baseline differences in PPI in mice, but it is possible that the $\alpha 7$ subunit may mediate the enhancement of PPI by nicotine. Future studies with $\alpha 7$ knock out mice can be used to address this issue.

\section{CONCLUSIONS}

The combination of behavioral, pharmacological, anatomical, and genetic techniques has begun to resolve the question of which subtypes of the $\mathrm{nAChR}$ mediate the various effects of nicotine and where in the brain these actions occur. Mice have now been generated that lack most of the individual subunits of the nAChR and have been used to begin to elucidate the subtypes responsible for nicotine's effects on reinforcement and learning. Future experiments with animals lacking combinations of subunits, or lacking nAChRs only in particular brain regions or at particular times during development will be very useful in continuing this work. Ultimately, these data should be useful in developing specific nicotinic agonists that may be used to treat cognitive or affective disorders.

\section{ACKNOWLEDGMENTS}

The authors would like to thank Robert Beech and Diann Stedman for critical reading of the manuscript. This work was supported by grants DA10455, DA00167, and DA07290 from the National Institutes of Health and The Christiane Brooks Johnson Foundation.

\section{REFERENCES}

Acri JB, Grunberg NE, Morse DE (1991): Effects of nicotine on the acoustic startle reflex amplitude in rats. Psychopharmacology 104(2):244-248
Acri JB, Morse DE, Popke EJ, Grunberg NE (1994): Nicotine increases sensory gating measured as inhibition of the acoustic startle reflex in rats. Psychopharmacology 114(2):369-374

Adler LE, Hoffer LD, Wiser A, Freedman R (1993): Normalization of auditory physiology by cigarette smoking in schizophrenic patients. Am J Psychiatry 150(12):1856-1861

Adler LE, Olincy A, Waldo M, Harris JO, Griffith J, Stevens K, Flach K, Nagarnoto H, Bickford P, Leonard S, Freedman R (1998): Schizophrenia, sensory gating, and nicotinic receptors. Schizophr Bull 24(2):189-202

Adler LE, Pachtrnan E, Franks RD, Pecevich M, Waldo MC, Freedman R (1982): Neurophysiological evidence for a defect in neuronal mechanisms involved in sensory gating in schizophrenia. Biol Psychiatry 17(6):639-654

Alkondon M, Albuquerque EX (1993): Diversity of nicotinic acetylcholine receptors in rat hippocampal neurons. I. Pharmacological and functional evidence for distinct structural subtypes. J Pharmacol Exp Ther 265(3):1455-1473

Allen RS, Cui C, Heinemann SF (1998): Gene targeted knock out of the beta3 neuronal nicotinic acetylcholine receptor subunit. Soc Neurosci Abstr 24:1341

Anand R, Conroy WG, Schoopfer R, Whiting P, Lindstrom J (1991): Neuronal nicotinic acetylcholine receptors expressed in Xenopus oocytes have a pentameric quaternary structure. J Biol Chem 266(17):11192-11198

Bannon AW, Decker MW, Holladay MW, Curzon P, Donnelly-Roberts D, Puttfarcken PS, Bitner RS, Diaz A, Dickenson AH, Porsolt RD, Williams M, Arneric SP (1998): Broad-spectrum, nonopioid analgesic activity by selective modulation of neuronal nicotinic acetylcholine receptors. Science 279(5347):77-81

Baruch I, Hemsley DR, Gray JA (1988): Differential performance of acute and chronic schizophrenics in a latent inhibition task. J Nerv Ment Dis 176(10):598-606

Benwell ME, Balfour DJ (1992): The effects of acute and repeated nicotine treatment on nucleus accumbens dopamine and locomotor activity. $\mathrm{Br} \mathrm{J}$ Pharmacol 105(4):849-856

Bitner RS, Nikkel AL, Curzon P, Arneric SP, Bannon AW, Decker MW (1998): Role of the nucleus raphe magnus in antinociception produced by ABT-594: Immediate early gene responses possibly linked to neuronal nicotinic acetylcholine receptors on serotonergic neurons. J Neurosci 18(14):5426-5432

Borlongan CY, Shytle RD, Ross SD, Shimizu T, Preeman TB, Cahill DW, Sanberg PR (1995): Nicotine protects against systemic kainic acid-induced excitotoxic effects. Exp Neurol 136(2):261-265

Breslau N (1995): Psychiatric comorbidity of smoking and nicotine dependence. Behav Genet 25(2):95-101

Brioni JD, O’Neill AB, Kim DJB, Decker MW (1993): Nicotinic receptor agonists exhibit anxiolytic-like effects on the elevated plus-maze test. Eur J Pharmacol 238:1-8

Brown ES, Rush AJ, McEwen BS (1999): Hippocampal remodeling and damage by corticosteroids: Implications for mood disorders. Neuropsychopharmacology 21 (4):474-484

Burling TA, Ziff DC (1988): Tobacco smoking: A comparison between alcohol and drug abuse inpatients. Addict Behav 13:185-190 
Caine SB, Geyer MA, Swerdlow NP (1991): Carbachol infusion into the dentate gyrus disrupts sensorimotor gating of startle in the rat. Psychopharmacology 105(3):347-354

Cao W, Burkholder T, Wilkins L, Collins AC (1993): A genetic comparison of behavioral actions of ethanol and nicotine in the mirrored chamber. Pharmacol Biochem Behav 45(4):803-809

Cartier GE, Yoshikami D, Gray WR, Luo S, Olivera BM, McIntosh JM (1996): A new alpha-conotoxin which targets alpha3beta2 nicotinic acetylcholine receptors. J Biol Chem 271(13):7522-7528

Clarke PB, Fibiger HC (1987): Apparent absence of nicotineinduced conditioned place preference in rats. Psychopharmacology 92(1):84-88

Clarke PB, Fu DS, Jakubovic A, Fibiger HC (1988): Evidence that mesolimbic dopaminergic activation underlies the locomotor stimulant action of nicotine in rats. J Pharmacol Exp Ther 246(2):701-708

Clarke PBS, Kumar R (1983): Characterization of the locomotor stimulant action of nicotine in tolerant rats. $\mathrm{Br} \mathrm{J}$ Pharmacol 80:587-594

Clarke PBS, Pert A (1985): Autoradiographic evidence for nicotine receptors in nigrostriatal and mesolimbic dopaminergic neurons. Brain Res 348:355-358

Cooper E, Couturier S, Ballivet M (1991): Pentameric structure and subunit stoichiometry of a neuronal nicotinic acetylcholine receptor. Nature 350:235-238

Corrigall WA, Franklin KM (1989): Nicotine maintains robust self-administration in rats on a limited access schedule. Psychopharmacology 99:473-478

Corrigall WA, Franklin KB, Coen KM, Clarke PB (1992): The mesolimbic dopaminergic system is implicated in the reinforcing effects of nicotine. Psychopharmacology 107(2-3):285-289

Costall B, Kelly ME, Naylor RJ, Onaivi ES (1989): The actions of nicotine and cocaine in a mouse model of anxiety. Pharmacol Biochem Behav 33:197-203

Cox BM, Goldstein A, Nelson WT (1984): Nicotine selfadministration in rats. Br J Pharmacol 83(1):49-55

Damaj MI, Martin BR (1993): Calcium agonists and antagonists of the dihydropyridine type: Effect on nicotineinduced antinociception and hypomotility. Drug Alcohol Depend 32(1):73-79

Decker MW, Brioni ID, Bannon AW, Arneric SP (1995): Diversity of neuronal nicotinic acetylcholine receptors: Lessons from behavior and implications for CNS therapeutics. Life Sci 56(8):545-570

Della Casa V, Hofer I, Feldon J (1999a): Latent inhibition in smokers vs. nonsmokers: Interaction with number or intensity of preexposures? Pharmacol Biochem Behav 62(2):353-359

Della Casa V, Hofer I, Weiner I, Feldon J (1999b): Effects of smoking status and schizotypy on latent inhibition. J Psychopharmacol 13(1):45-57

Dineley-Miller K, Patrick J (1992): Gene transcripts for the nicotinic acetylcholine receptor subunit, beta4, are distributed in multiple areas of the rat central nervous system. Mol Brain Res 16(3-4):339-344

Donnelly-Roberts DL, Puttfarcken PS, Kuntzweiler TA, Briggs CA, Anderson DJ, Campbell JE, Piattoni-Kaplan
M, McKenna DG, Wasicak JT, Holladay MW, Williams M, Arneric SP (1998): ABT-594 [(R)-5-(2-azetidinylmethoxy)-2-chloropyridine]: A novel, orally effective analgesic acting via neuronal nicotinic acetylcholine receptors. I. In vitro characterization. J Pharmacol Exp Ther 285(2):777-786

Dunnett SB, Martel FL (1990): Proactive interference effects on short-term memory in rats. I. Basic parameters and drug effects. Behav Neurosci 104(5):655-665

Elgoyhen AB, Johnson DS, Boulter J, Vetter DE, Heinemann S (1994): Alpha 9: An acetylcholine receptor with novel pharmacological properties expressed in rat cochlear hair cells. Cell 79:705-715

Elmes D, Jarrard L, Swart P (1975): Helplessness in hippocampectomized rats: Response perseveration? Physiol Psychol 3(1):51-55

Epping-Jordan MP, Watkins SS, Koob GF, Markou A (1998): Dramatic decreases in brain reward function during nicotine withdrawal. Nature 393:76-79

Everitt BJ, Robbins TW (1997): Central cholinergic systems and cognition. Annu Rev Psychol 48:649-684

Faiman CP, de Erausquin GA, Baratti CM (1991): The enhancement of retention induced by vasopressin in mice may be mediated by an activation of central nicotinic cholinergic mechanisms. Behav Neural Biol 56:183199

Feldon J, Weiner I (1992): From an animal model of an attentional deficit towards new insights into the pathophysiology of schizophrenia. J Psychiatry Res 26(4):345-366

File SE, Kenny PJ, Ouagazzal AM (1998): Bimodal modulation by nicotine of anxiety in the social interaction test: Role of the dorsal hippocampus. Behav Neurosci 112(6):1423-1429

Flores CM, Rogers SW, Pabreza LA, Wolff BB, Kellar KJ (1992): A subtype of nicotinic cholinergic receptor in rat brain is composed of alpha4-subunit and beta2-subunit and is upregulated by chronic nicotine treatment. Mol Pharmacol 41(1):31-37

Freedman R, Coon H, Myles-Worsley M, Orr-Urtreger A, Olincy A, Davis A, Polymeropoulos M, Holik J, Hopkins J, Hoff M, Rosenthal J, Waldo MC, Reimherr F, Wender P, Yaw J, Young DA, Breese CR, Adams C, Patterson D, Adler LE, Kruglyak L, Leonard S, Byerley W (1997): Linkage of a neurophysiological deficit in schizophrenia to a chromosome 15 locus. Proc Natl Acad Sci USA 94(2):587-592

Freedman R, Hall M, Adler EE, Leonard S (1995): Evidence in postmortem brain tissue for decreased numbers of hippocampal nicotinic receptors in schizophrenia. Biol Psychiatry 38(1):22-33

Fu Y, Matta SG, James TJ, Sharp BM (1998): Nicotineinduced norepinephrine release in the rat amygdala and hippocampus is mediated through brainstem nicotinic cholinergic receptors. J Pharmacol Exp Ther 284(3):1188-1196

Galzi J-L, Revah F, Bessis A, Changeux J-P (1991): Functional architecture of the nicotinic acetylcholine receptor: From electric organ to brain. Annu Rev Pharmacol 31:37-72

Gould TJ, Wehner JM (1999): Nicotine enhancement of contextual fear conditioning. Behav Brain Res 102(1-2):31-39 
Grady S, Marks MJ, Wonnacott S, Collins AC (1992): Characterization of nicotinic receptor-mediated $[3 \mathrm{H}]$ dopamine release from synaptosomes prepared from mouse striatum. J Neurochem 59(3):848-856

Gray JA (1988): Behavioural and neural-system analyses of the actions of anxiolytic drugs. Pharmacol Biochem Behav 29(4):767-769

Gray JA (1998): Integrating schizophrenia. Schizophr Bull 24(2):249-266

Gray R, Rajan AS, Radcliffe KA, Yakehiro M, Dani JA (1996): Hippocampal synaptic transmission enhanced by low concentrations of nicotine. Nature 383:713-716

Henningfield JE, Miyasato K, Jasinski DR (1983): Cigarette smokers self-administer intravenous nicotine. Pharmacol Biochem Behav 19:887-890

Hentall ID, Gollapudi L (1995): The interpeduncular nucleus regulates nicotine's effects on free-field activity. Neuroreport 6(18):2469-2472

Hildebrand BE, Nomikos GG, Bondjers C, Nisell M, Svensson TH (1997): Behavioral manifestations of the nicotine abstinence syndrome in the rat: Peripheral versus central mechanisms. Psychopharmacology 129(4):348-356

Hildebrand BE, Nomikos GG, Hertel P, Schilstrom B, Svensson TH (1998): Reduced dopamine output in the nucleus accumbens but not in the medial prefrontal cortex in rats displaying a mecamylamine-precipitated nicotine withdrawal syndrome. Brain Res 779(1-2):214-225

Hill JA Jr, Zoli M, Bourgeois J-P, Changeux J-P (1993): Immunocytochemical localization of a neuronal nicotinic receptor: The $\beta 2$ subunit. J Neurosci 13(4):1551-1568

Horger BA, Giles MK, Schenk S (1992): Preexposure to amphetamine and nicotine predisposes rats to selfadminister a low dose of cocaine. Psychopharmacology 107(2-3):271-276

Hughes JR, Higgins ST, Bickel WK (1994): Nicotine withdrawal versus other drug withdrawal syndromes: Similarities and dissimilarities. Addiction 89(11):1461-1470

Huston-Lyons D, Sarkar M, Kornetsky C (1993): Nicotine and brain-stimulation reward: Interactions with morphine, amphetamine and pimozide. Pharmacol Biochem Behav 46(2):453-457

James JR, Nordberg A (1995): Genetic and environmental aspects of the role of nicotinic receptors in neurodegenerative disorders: Emphasis on Alzheimer's disease and Parkinson's disease. Behav Genet 25(2):149-159

Joseph MH, Peters SL, Gray JA (1993): Nicotine blocks latent inhibition in rats: Evidence for a critical role of increased functional activity of dopamine in the mesolimbic system at conditioning rather than pre-exposure. Psychopharmacology 110(1-2):187-192

Jurna I, Krauss P, Baldauf J (1993): Depression by nicotine of pain-related nociceptive activity in the rat thalamus and spinal cord. Clin Investig 72(1):65-73

Kathol RG, Jaeckle RS, Lopez JF, Meller WH (1989): Pathophysiology of HPA axis abnormalities in patients with major depression: An update. Am J Psychiatry 146(3):311-317

Kelsey J, Baker M (1983): Ventromedial septal lesions in rats reduce the effects of inescapable shock on escape performance and analgesia. Behav Neurosci 97(6):945-961
Kelz MB, Chen J, Carlezon WA, Whisler K, Gilden L, Beckman A, Steffen C, Zheng Y-J, Marotti L, Self DW, Tkatch T, Baranauskas G, Surmeier DJ, Neve RL, Duman RS, Picciotto MR, Nestler EJ (1999): Expression of the transcription factor Delta FosB in the brain controls sensitivity to cocaine. Nature 401:272-276

Koob GF (1992): Drugs of abuse: Anatomy, pharmacology and function of reward pathways. Trends Pharmacol Sci 13(5):177-184

Lawrence AD, Sahakian BJ (1998): The cognitive psychopharmacology of Alzheimer's disease: Focus on cholinergic systems. Neurochem Res 23(5):787-794

Le Novère N, Changeux J-P (1995): Molecular evolution of the nicotinic acetylcholine receptor: An example of multigene family in excitable cells. J Mol Evol 40:155-172

Le Novère N, Zoli M, Changeux J-P (1996): Neuronal nicotinic receptor alpha 6 subunit mRNA is selectively concentrated in catecholaminergic nuclei of the rat brain. Eur J Neurosci 8:2428-2439

Le Novère $N$, Zoli $M$, Léna $C$, Ferrari $R$, Picciotto $M R$ Changeux J-P (1999): Involvement of alpha 6 nicotinic receptor subunit in nicotine-elicited locomotion, demonstrated by in vivo antisense oligonucleotide infusion. Neuroreport 10(12):2497-2501

Léna CJ, Changeux IP, Mulle C (1993): Evidence for "preterminal" nicotinic receptors on GABAergic axons in the rat interpeduncular nucleus. J Neurosci 13(6):2680-2688

Léna C, de Kerchove D'Exaerde A, Cordero-Erausquin M, Le Novère N, Arroyo-Jimenez M, Changeux J-P (1999): Diversity and distribution of nicotinic acetylcholine receptors in the locus ceruleus neurons. Proc Natl Acad Sci USA 96(21):12126-12131

Levin ED (1992): Nicotinic systems and cognitive function. Psychopharmacology 108(4):417-431

Levin ED, Simon BB (1998): Nicotinic acetylcholine involvement in cognitive function in animals. Psychopharmacology 138(3-4):217-230

Listerud M, Brussaard AB, Devay P, Colman DR, Role LW (1991): Functional contribution of neuronal AChR subunits revealed by antisense oligonucleotides. Science 254:1518-1521

Lu Y, Grady S, Marks MJ, Picciotto M, Changeux JP, Collins AC (1998): Pharmacological characterization of nicotinic receptor-stimulated GABA release from mouse brain synaptosomes. J Pharmacol Exp Ther 287(2):648-657

Luetje CW, Patrick J (1991): Both alpha- and beta-subunits contribute to the agonist sensitivity of neuronal nicotinic acetylcholine receptors. J Neurosci 11(3):837-845

Luntz-Leybman V, Bickford PC, Freedman R (1992): Cholinergic gating of response to auditory stimuli in rat hippocampus. Brain Res 587(1):130-136

MacDermott AB, Role LW, Siegelbaum SA (1999): Presynaptic ionotropic receptors and the control of transmitter release. Annu Rev Neurosci 22:443-485

Malin DH, Lake JR, Newlin-Maultsby P, Roberts LK, Lanier JG, Carter VA, Cunningham JS, Wilson OB (1992): Rodent model of nicotine abstinence syndrome. Pharmacol Biochem Behav 43(3):779-784

Marin P, Maus M, Desagher S, Glowinski J, Premont J (1994): Nicotine protects cultured striatal neurones against 
N-methyl-D-aspartate receptor-mediated neurotoxicity. Neuroreport 5(15):1977-1980

Marks M, Campbell S, Romm E, Collins A (1991): Genotype influences the development of tolerance to nicotine in the mouse. J Pharmacol Exp Ther 259(1):392-402

Marks MJ, Stitzel JA, Collins AC (1989): Genetic influences on nicotine responses. Pharmacol Biochem Behav 33:667-678

Marks MJ, Whiteaker P, Calcaterra J, Stitzel JA, Bullock AE, Grady SR, Picciotto MR, Changeux JP, Collins AC (1999): Two pharmacologically distinct components of nicotinic receptor-mediated rubidium efflux in mouse brain require the beta 2 subunit. J Pharmacol Exp Therap 289(2):1090-1103

Marshall DL, Redfern PH, Wonnacott S (1997): Presynaptic nicotinic modulation of dopamine release in the three ascending pathways studied by in vivo microdialysis: Comparison of naive and chronic nicotine-treated rats. J Neurochem 68(4):1511-1519

Marubio L, del Mar Arroyo-Jimenez M, Cordero-Erausquin $\mathrm{M}$, Léna $\mathrm{C}$, Le Novère $\mathrm{N}$, de Kerchove d'Exaerde $\mathrm{A}$, Huchet M, Damaj MI, Changeux J-P (1999): Reduced antinociception in mice lacking neuronal nicotinic receptor subunits. Nature 398:805-810

McEwen BS, Sapolsky RM (1995): Stress and cognitive function. Curr Opin Neurobiol 5(2):205-216

McGaugh JL, Cahill L (1997): Interaction of neuromodulatory systems in modulating memory storage. Behav Brain Res 83(1-2):31-38

McGaugh JL, Cahill L, Roozendaal B (1996): Involvement of the amygdala in memory storage: Interaction with other brain systems. Proc Natl Acad Sci USA 93(24):13508-13514

McGehee DS, Heath MJ, Crelber S, Devay P, Role LW (1995): Nicotine enhancement of fast excitatory synaptic transmission in CNS by presynaptic receptors. Science 269(5231):1692-1696

McGehee DS, Role LW (1996): Presynaptic ionotropic receptors. Curr Opin Neurobiol 6(3):342-349

Menard J, Treit D (1996): Lateral and medial septal lesions reduce anxiety in the plus-maze and probe-burying tests. Physiol Behav 60(3):845-853

Merlo Pich E, Pagliusi SR, Tessari M, Talabot-Ayer D, Hooft van Huijsduijnen $R$, Chiamulera C (1997): Common neural substrates for the addictive properties of nicotine and cocaine. Science 275:83-86

Mifsud J-C, Hernandez L, Hoebel BG (1989): Nicotine infused into the nucleus accumbens increases synaptic dopamine as measured by in vivo microdialysis. Brain Res 478:365-367

Museo E, Wise RA (1990): Microinjections of a nicotinic agonist into dopamine terminal fields: Effects on locomotion. Pharmacol Biochem Behav 37(1):113-116

Museo E, Wise RA (1994): Place preference conditioning with ventral tegmental injections of cytisine. Life Sci 55(15):1179-1186

Museo E, Wise RA (1995): Cytisine-induced behavioral activation: Delineation of neuroanatomical locus of action. Brain Res 670(2):257-263

Nisell M, Nomikos GG, Svensson TH (1994): Infusion of nicotine in the ventral segmental area or the nucleus accumbens of the rat differentially affects accumbal dopamine release. Pharmacol Toxicol 75(6):348-352

Nisell M, Nomikos GG, Svensson TH (1995): Nicotine dependence, midbrain dopamine systems and psychiatric disorders. Pharmacol Toxicol 16(3):157-162

Nordberg A (1994): Human nicotinic receptors-their role in aging and dementia. Neurochem Intl 25(1):93-97

Nye HE, Nestler EJ (1996): Induction of chronic Fos-related antigens in rat brain by chronic morphine administration. Mol Pharmacol 49(4):636-645

Orr-Urtreger A, Goldner FM, Saeki M, Lorenzo I, Golberg L, De Biasi M, Dani JA, Patrick JW, Beaudet AL (1997): Mice deficient in the alpha7 neuronal nicotinic acetylcholine receptor lack alpha-bungarotoxin binding sites and hippocampal fast nicotinic currents. J Neurosci 17(23):9165-9171

Ouagazzal AM, Kenny PJ, File SE (1999): Modulation of behaviour on trials 1 and 2 in the elevated plus-maze test of anxiety after systemic and hippocampal administration of nicotine. Psychopharmacology 144(1):54-60

Overstreet DH (1993): The Flinders sensitive line rats: A genetic animal model of depression. Neurosci Biobehav Rev 17(1):51-68

Pauly JR, Collins AC (1993): An autoradiographic analysis of alterations in nicotinic cholinergic receptors following one week of corticosterone supplementation. Neuroendocrinology 57:262-271

Paylor R, Nguyen M, Crawley JN, Patrick J, Beaudet A, OrrUrtreger A (1998): Alpha-7 nicotinic receptor subunits are not necessary for hippocampal-dependent learning or sensorimotor gating - a behavioral characterization of ACR7-deficient mice. Learning \& Memory 5(4-5): 302-316

Picciotto MR, Zoli M, Léna C, Bessis A, Lallemand Y, Le Novère $N$, Vincent $P$, Merlo Pich E, Brulet $P$, Changeux J-P (1995): Abnormal avoidance learning in mice lacking functional high-affinity nicotine receptor in the brain. Nature 374:65-67

Picciotto MR, Zoli M, Rimondini R, Léna C, Marubio LM, Merlo Pich E, Fuxe K, Changeux JP (1998): Acetylcholine receptors containing the beta-2 subunit are involved in the reinforcing properties of nicotine. Nature 391:173-177

Picciotto MR, Zoli M, Zachariou V, Changeux J-P (1997): Contribution of nicotinic acetylcholine receptors containing the $\beta 2$ subunit to the behavioural effects of nicotine. Biochem Soc Trans 25:824-829

Pidoplichko VI, Debiasi M, Williams JT, Dani JA (1997): Nicotine activates and desensitizes midbrain dopamine neurons. Nature 396:401-404

Ramirez-Latorre J, Yu CR, Qu X, Perin F, Karlin A, Role L (1996): Functional contributions of alpha5 subunit to neuronal acetylcholine receptor channels. Nature 380:347-351

Rasmussen K, Czachura JF (1995): Nicotine withdrawal leads to increased firing rates of midbrain dopamine neurons. Neuroreport 7(1):329-332

Rathouz MM, Berg DK (1994): Synaptic-type acetylcholine receptors raise intracellular calcium levels in neurons by two mechanisms. J Neurosci 14(11 Pt 2):6935-6945

Riekkinen P Jr, Riekkinen M, Sirvio J (1993): Cholinergic 
drugs regulate passive avoidance performance via the amygdala. J Pharmacol Exp Ther 267(3):1484-1492

Risner ML, Goldberg SR (1983): A comparison of nicotine and cocaine self-administration in the dog: Fixed-ratio and progressive-ratio schedules of intravenous drug infusion. J Pharmacol Exp Ther 224(2):319-326

Roberts RG, Stevenson JE, Westerman RA, Pennefather J (1995): Nicotinic acetylcholine receptors on capsaicinsensitive nerves. Neuroreport 6(11):1578-1582

Rochford J, Sen AP, Quirion R (1996): Effect of nicotine and nicotinic receptor agonists on latent inhibition in the rat. J Pharmacol Exp Ther 277(3):1267-1275

Role LW (1992): Diversity in primary structure and function of neuronal nicotinic acetylcholine receptor channels. Curr Opin Neurobiol 2(3):254-262

Rollins Y, Stevens K, Harris K, Hall M, Rose G, Leonard S (1993): Reduction in auditory gating following intracerebroventricular application of alpha-bungarotoxin binding site ligands and alpha-7 antisense oligonucleotides. Soc Neurosci Abstr 19:837

Rowell PP (1995): Nanomolar concentrations of nicotine increase the release of $[3 \mathrm{H}]$ dopamine from rat striatal synaptosomes. Neurosci Lett 189(3):171-175

Rush AJ, Giles DE, Schlesser MA, Orsulak PJ, Parker CR Jr, Weissenburger M, Crowley GT, Khatami M, Vasavada N (1996): The dexamethasone suppression test in patients with mood disorders. J Clin Psychiatry 57(10): 470-484

Salin-Pascual RJ, de la Fuente JR, Galicia-Polo L, DruckerColin R (1995): Effects of transdermal nicotine on mood and sleep in nonsmoking major depressed patients. Psychopharmacology 121(4):476-479

Salin-Pascual RJ, Rosas M, Jiminez Genchi A, Rivera Meza BL, Delgado Parra V (1996): Antidepressant effect of transdermal nicotine patches in nonsmoking patients with major depression. J Clin Psychiatry 57(9):387-389

Sargent PB (1993): The diversity of neuronal nicotinic acetylcholine receptors. Annu Rev Neurosci 16:403-443

Schilstrom B, Nomikos GG, Nisell M, Hertel P, Svensson TH (1998a): N-methyl-D-aspartate receptor antagonism in the ventral tegmental area diminishes the systemic nicotine-induced dopamine release in the nucleus accumbens. Neuroscience 82(3):781-789

Schilstrom B, Svensson HM, Svensson TH, Nomikos GG (1998b): Nicotine and food induced dopamine release in the nucleus accumbens of the rat: Putative role of alpha7 nicotinic receptors in the ventral tegmental area. Neuroscience 85(4):1005-1009

Seguela P, Wadiche J, Dineley-Miller K, Dani JA, Patrick JW (1993): Molecular cloning, functional properties, and distribution of rat brain-alpha7-a nicotinic cation channel highly permeable to calcium. J Neurosci 13(2):596604

Semba J, Mataki C, Yamada S, Nankai M, Toru M (1998): Antidepressantlike effects of chronic nicotine on learned helplessness paradigm in rats. Biol Psychiatry 43(5):389391

Shippenberg TS, Heidbreder C, Lefevour A (1996): Sensitization to the conditioned rewarding effects of morphine: Pharmacology and temporal characteristics. Eur J Pharmacol 299(1-3):33-39
Shoaib M, Stolerman IP, Kumar RC (1994): Nicotine-induced place preferences following prior nicotine exposure in rats. Psychopharmacology 113(3-4):445-452

Smith BR, Horan JT, Gaskin S, Amit Z (1999): Exposure to nicotine enhances acquisition of ethanol drinking by laboratory rats in a limited access paradigm. Psychopharmacology 142(4):408-412

Stevens KE, Freedman R, Collins AC, Hall M, Leonard S, Marks MJ, Rose GM (1996): Genetic correlation of inhibitory gating of hippocampal auditory evoked response and alpha-bungarotoxin-binding nicotinic cholinergic receptors in inbred mouse strains. Neuropsychopharmacology 15(2):152-162

Stevens KE, Kem WR, Mahnir VM, Freedman R (1998): Selective alpha7-nicotinic agonists normalize inhibition of auditory response in DBA mice. Psychopharmacology 136(4):320-327

Stevens KE, Wear KD (1997): Normalizing effects of nicotine and a novel nicotinic agonist on hippocampal auditory gating in two animal models. Pharmacol Biochem Behav 57(4):869-874

Suh HW, Song DK, Choi SR, Chung KM, Kim YH (1996): Nicotine enhances morphine- and beta-endorphininduced antinociception at the supraspinal level in the mouse. Neuropeptides 30(5):479-484

Summers KL, Giacobini E (1995): Effects of local and repeated systemic administration of (-)nicotine on extracellular levels of acetylcholine, norepinephrine, dopamine, and serotonin in rat cortex. Neurochem Res 20(6):753-759

Suzuki T, Ise Y, Tsuda M, Maeda J, Misawa M (1996): Mecamylamine-precipitated nicotine withdrawal aversion in rats. Eur J Pharmacol 314(3):281-284

Swerdlow N, Caine S, Braff D, Geyer M (1992): The neural substrates of sensorimotor gating of the startle reflex: A review of recent findings and their implications. J Psychopharmacol 6(2):176-190

Thornton JC, Dawe S, Lee C, Capstick C, Corr PJ, Cotter P, Frangou S, Gray NS, Russell MA, Gray JA (1996): Effects of nicotine and amphetamine on latent inhibition in human subjects. Psychopharmacology 127(2): 164-173

Tizabi Y, Overstreet DH, Rezvani AH, Louis VA, Clark E Jr, Janowsky DS, Kling MA (1999): Antidepressant effects of nicotine in an animal model of depression. Psychopharmacology 142(2):193-199

Traynor JR (1998): Epibatidine and pain. Br J Anaesth 81(1):69-76

Treit D, Menard J (1997): Dissociations among the anxiolytic effects of septal, hippocampal, and amygdaloid lesions. Behav Neurosci 111(3):653-658

Tripathi HL, Mattin BR, Aceto MD (1982): Nicotine-induced antinociception in rats and mice: Correlation with nicotine brain levels. J Pharm Exp Therap 221(1):91-96

US Department of Health and Human Services (1988): The Health Consequences of Smoking: Nicotine Addiction. A Report of the Surgeon General. Washington, D.C. U.S. Government Printing Office

Vale A, Green S (1996): Effects of chlordiazepoxide, nicotine and d-amphetamine in the rat potentiated startle model of anxiety. Behav Pharmacol 7(2):138-143 
van Duijn CM, Hofman A (1991): Relation between nicotine intake and Alzheimer's disease. BMJ 302(6791):1491-1494

Vetter DE, Liberrman MC, Mann J, Barhanin J, Boulter J, Brown MC, Saffiote-Kolman J, Heinemann SF, Elgoyhen AB (1999): Role of alpha9 nicotinic ACh receptor subunits in the development and function of cochlear efferent innervation. Neuron 23(1):93-103

Vetter DE, Stitzel JA, Mann J, Elgoyhen AB, Saffiote J, Barharun J, Collins AC, Heinemann SF (1997): Altered cochlear efferent fiber innervation and acoustic startle reflex in alpha9 $\mathrm{nAChR}$ subunit knockout mice. Soc Neurosci Abstr 23(1-2):732

Vidal C, Changeux JP (1993): Nicotinic and muscarinic modulations of excitatory synaptic transmission in the rat prefrontal cortex in vitro. Neuroscience 56(1):23-32

Wada E, Wada K, Boulter J, Deneris E, Heinemann S, Patrick J, Swanson LW (1989): Distribution of Alpha2, Alpha3, Alpha4, and Beta2 neuronal nicotinic subunit mRNAs in the central nervous system: A hybridization histochemical study in rat. J Comp Neurol 284:314-335

Weiner I (1990): Neural substrates of latent inhibition: The switching model. Psychol Bull 108(3):442-461

Weiner I, Feldon J (1997): The switching model of latent inhibition: An update of neural substrates. Behav Brain Res 88(1):11-25

Wewers ME, Dhatt RK, Snively TA, Tejwani GA (1999): The effect of chronic administration of nicotine on antinociception, opioid receptor binding and met-enkelphalin levels in rats. Brain Res 822(1-2):107-113

Whiteaker P, Marks MJ, Mclntosh JM, Picciotto MR, Changeux J-P, Collins AC (1998): Location and composition of $\alpha$-conotoxin MII ( $\alpha$-Ctx MII) binding nicotinic receptors in mouse brain. Soc Neurosci Abstr 24:836

Wonnacott S, Drasdo A, Sanderson E, Rowell P (1990): Presynaptic nicotinic receptors and the modulation of transmission release. In Block G, Marsh J (eds), The Biology of Nicotine Dependence. Chichester, Wiley, pp 87-105

Wonnacott S, Irons J, Rapier C, Thorne B, Lunt GG (1989): Presynaptic modulation of transmitter release by nicotinic receptors. In Nordberg A, Fuxe K, Holmstedt B, Sundwall A (eds), Progress in Brain Research, Amsterdam, The Netherlands, Elsevier Science Publishers, pp 157-163

$\mathrm{Xu} \mathrm{W,} \mathrm{Gelber} \mathrm{S,} \mathrm{Orr-Urtreger} \mathrm{A,} \mathrm{Armstrong} \mathrm{D,} \mathrm{Lewis} \mathrm{RA,}$ Ou CN, Patrick J, Role L, De Biasi M, Beaudet AL (1999a): Megacystis, mydriasis, and ion channel defect in mice lacking the alpha3 neuronal nicotinic acetylcholine receptor. Proc Natl Acad Sci USA 96(10):5746-5751

$\mathrm{Xu}$ W, Orr-Urtreger A, Nigro F, Gelber S, Sutcliffe C, Armstrong D, Patrick J, Role L, Beaudet A, De Biasi M (1999b): Multiorgan autonomic dysfunction in mice lacking the beta2 and the beta4 subunits of neuronal nicotinic acetylcholine receptors. J Neurosci 19(21): 92989305

Xu W, Sutcliffe CB, Lorenzo I, Goldberg L, Dang H, Patrick J, Beaudet AL, Orr-Urtreger A (1997): Gene targeting of the alpha7 and beta2 subunits and the beta4, alpha3 and alpha5 cluster of neuronal nicotinic acetylcholine receptors. Soc Neurosci Abstr 23:391

Yang X, Criswell HE, Breese GR (1996): Nicotine-induced inhibition in medial septum involves activation of presynaptic nicotinic cholinergic receptors on gamma-aminobutyric acid-containing neurons. J Pharmacol Exp Ther 276(2):482-489

Yu CR, Role LW (1998): Functional contribution of the alpha7 subunit to multiple subtypes of nicotinic receptors in embryonic chick sympathetic neurons. J Physiol 509(3):651-665

Zachariou V, Changeux J-P, Picciotto MR (1997): Place preference conditioning by cocaine and morphine in mice lacking the high affinity neuronal nicotinic receptor. Soc Neurosci Abstr 23:1098

Zarrindast MR, Pazouki M, Nassiri-Rad S (1997): Involvement of cholinergic and opioid receptor mechanisms in nicotine-induced antinociception. Pharmacol Toxicol 81(5):209-213

Zoli M, Jansson A, Sykova E, Agnati LF, Fuxe K (1999a): Volume transmission in the CNS and its relevance for neuropsychopharmacology. Trends Pharmacol Sci 20(4): 142-150

Zoli M, Le Novère N, Hill JA, Changeux J-P (1995): Developmental regulation of nicotinic receptor subunit mRNAs in the rat central and peripheral nervous systems. J Neurosci 15(3):1912-1939

Zoli M, Léna C, Picciotto MR, Changeux J-P (1998): Identification of four classes of brain nicotinic receptors using B2-mutant mice. J Neurosci 18:4461-4472

Zoli M, Picciotto MR, Ferrari R, Cocchi D, Changeux J-P (1999b): Increased neurodegeneration during ageing in mice lacking high-affinity nicotine receptors. EMBO J 18(5):1235-1244 